\title{
The emergence, development and historical continuity of the sephardi courtier class
}

\author{
NORMan A. StILLMan*
}

There is a considerable body of scholarly literature devoted to the topic of Jewish retainers and officials who throughout history, have served in one capacity or another at the court of Gentile rulers. Much of this literature deals with the lives and careers of individual Jewish courties in the Islamic world or in Christendom, especially those who acted as "shtadlanim", official or unofficial representatives and intercessors for their people before the authorities. Ever since the rise of the Wissenschaft des Judentums, a considerable portion of the literature has dealt with the unique cultural milieu and ethos of the Jewish courtiers in medieval al-Andalus. A less extensive body of work - although by no means inconsiderable - has discussed the Sephardi courtier elite in the Christian kingdoms of the Reconquista. However, very little of this scholarly corpus has examined the phenomenon of Jewish courtiers sociologically or diachronically, with the notable exception of Selma Stern's classic monograph on the Hofjude in seventeenth - and eighteenth - century Central Europe or of Walter P. Zenner's recent groundbreaking article which attempts to analyze data on Jewish courties in the Muslim and Christian worlds in the light of social scientific theories. Such scholarly treatments of the Sephardi courtier phenomenon remain a major desideratum ${ }^{1}$.

* State University of N. York at Binghamton.

1 For a general introduction to the bibliography on Shtadlanim, see «Shtadlan», EJ, no. 14, págs. 1462-1463. For court Jews in the medieval Muslim East, see Fischel, Walter J., Jews in the economic and political life of Mediaeval Islam, 2nd ed. New York 1969; STILLMAN, Norman A., The Jews of Arab lands: A history and source book. Philadelphia 1979; and GoITEIN, S. D., A Mediterranean society II: The community and IV: The individual. Berkeley and Los Angeles 1969 and 1988, especially págs. 374-380 and 254-272, respectively (et passim). For court Jews and their culture in Islamic Spain, see WEISs, Joseph, "Tarbût Hașrânît ve-Shîra Haṣrânît: Berûrîm le-havhânat shîrat Sefârad ha- “Ivrît"», World Congress of Jewish Studies I. Jerusalem 1952, págs. 
What I should like to do in this paper is to offer an initial and tentative sociohistorical overview of a distinct Sephardi courtier class that emerged and evolved in al-Andalus, further developed in medieval Christian Spain, and in many respects continued in the lands of the Islamic Diaspora after 1492. Throughout its long history, the Sephardi courtier elite maintained a conscious sense of its own collective identity and a well defined group ethos. That is, it was indeed a sociologically delineated class "für sich" with esprit de corps, interaction among its members, and a capacity for political action on behalf of its interests, and it was not just a class "an sich". It was a far more cohesive, definable group than its predecessor, the Jewish courtier elite in ${ }^{\mathrm{C}} \mathrm{Abbasid}$ Baghdad or the contemporary court Jews in the Fatimid caliphate. In addition to being a conscious class, the Sephardi courtier elite constituted a distinct subculture which was set within the matrices of both Jewish and Gentile society and which assimilated cultural elements from both milieus into a uniquely self-characterizing social and cultural fusion ${ }^{2}$.

396-402; AshTOR, Eliyahu, The Jews of Moselm Spain. Philadelphia 1973-1984, 3 vols.; STILLMAN, Norman A., "Aspects of Jewish Life in Islamic Spain", in Aspects of Jewish culture in the Middle Age, ed. Paul E. Szarmach. Albany 1979, págs. 51-84; SAFRAN, Bezalel, "Bahya ibn Paquda's attitude toward the Courtier Class", in Studies in Medieval Jewish history and literature, ed. Isadore Twersky. Cambridge, Mass. and London 1979, págs. 154-196; and especially Gerson D. Cohen's essays and notes to edition and translation of ABRAHAM IBN DAUD, The Book of Tradition: Sefer ha-Qabbalah. Philadelphia 1967. For Jewish courtiers in Christian Spain, see BAER, Yitzhak, A history of the Jews in Christian Spain. Philadelphia 1971, 2 vols.; BeInART, Haim, "Demûtâh shel ha-Hașrânût ha-Yehûdît bi-Stârad ha-Nôșerî̀t", in Qevûșôt cllît û-Shekhâvôt Manhîgôt be-Tôldôt Yisrâ'êl ûve-Tôldôt hâ- Amîm. Jerusalem 1967, págs. 55-71; SEptimus, Bernard, "Power and Piety in Thirteenth-Century Catalonia". Studies in medieval Jewish history and literature, págs. 197-230; and idem, Hispano-Jewish culture in transition. Cambridge, Mass. and London 1982. For Sephardi courtiers in the Islamic world after the Expulsion, see Roth, Cecil, The house of Nasi: The Duke of Naxos. Philadelphia 1948; LEWIS, Bernard, “The Privilege Granted by Mehmed II to His Physician", BSOAS, no. 14, 1952, págs, 550-663; idem, The Jews of /s/am. Princeton 1984, págs. 136-137 and 144; StIllman, Norman A. and Stillman, Yedida K., "The Jewish Courtier Class in Late Eighteenth-Century morocco as Seen Through the Eyes of Samuel Romanelli", in The Islamic world from classical to modern times: Essays in honor of Bernard Lewis, eds. C. E. Bosworth et al. Princeton 1989, págs. 845-854. SteRn, Selma, The Court Jew: $A$ contribution to the history of absolutism in Europe, with a new introduction by Egon Mayer. New Brunswick 1985; and ZENNER, Walter F., "Jewish retainers as power brokers", JQR, no. 81:1-2, 1990, págs. 127-149. Finally, two other important comparative, social scientific studies which deal in part with the phenomenon are Cosen, Lewis, "The alien as servant of power: Court Jews and Christian renegades», American Sociological Review, no. 37, 1972, págs. 574-581; and CAHNMAN, W., "Pariahs, strangers, and Court-Jews: A conceptual classification", Sociological Analysis, no. 35, 1974, págs. 155-156. There is still no comprehensive look at the culture of the Sephardi courtier class as has been undertaken by Elke Stein-Hölkeskamp for the aristocracy of ancient Greece and by numerous other scholars for the nobility of various European nations. See SteIN-HölkeSkAMP, Elke, Ade/skultur und Polisgesel/schaft: Studien zum griechischen Adel in archaischer und kalssischer Zeit. Stuttgart 1989.

2 For a good survey of the salient sociological views on class and stratification, see BENDIX, 
The emergence of the Sephardi courtier class with its own culture, values, and lifestyle can be traced back to the period of Andalusian national assertion and self-realization in the tenth century, when 'Abd alRaḥân III al-Nâș̣r declared an independent caliphate in 929. Prior to this time, we hear of an occasional Jew in the entourage of the Umayyad amirs, such as Abu 'I-Naș Manșafur, who was court musician to the amir al-H kam I (796-822), but none of any real political prominence and certainly giving no impression as belonging to a specific status group ${ }^{3}$.

The actual genesis of the Sephardi courtier class can be specifically linked to the rise of a single individual, the remarkable physician, diplomat, and statesman, Hasday Ibn Shaprût (905-965), who served at the court of ‘Abd al-Rahân III and al-Hakam II (961-976). Initially, Hsday's place at court was as member of the dîwân al-atibbâ, or palace medical staff. Along with the roles of banker, purveyor, tax official, or intermediary of some sort, that of physician was one of the most typical forms of entrée for Jews into ruling circles throughout the Islamic world. Indeed, Hasday's only other official position was that of a supervisor of customs (also a role not infrequently filled by dhimmîs in the Muslim East aswell). In addition to these regular offices, Hasday served as a trusted advisor to the caliphs, and according to both Latin and Arabic sources, he was charged with delicate diplomatic negotiations with the Christian kingdoms of Northern Iberia and with the Holy Roman and Byzantine Empires ${ }^{4}$.

Hasday must be seen as the progenitor of the Sephardi courtier class, for in almost every respect, he set pattern that would be followed by later Jewish courtiers. First, he was a highly acculturated and -no less important- a highly cultured individual, part of the interconfessional fellowship of men of science and philosophy which typified the Hellenistic renascence in medieval Islam during the period dubbed by S. D. Goitein as the "Intermediate Civilization». Indeed, it was, among other things, the

Reinhardt and MARTIN LIPSET, Seymour (eds.), Class, status, and power: Social stratification in comparative perspective, 2nd ed. New York and London 1966. See also the important discussion in SPEncer, Martin E., «Images of Groups», Archives Européennes de Sociologie, no. 16:2, 1975, págs. 194-214. For a sophisticated discussion of the general lines of the process of social and cultural contact, diffusion, and formation in the medieval Iberian Peninsula, see GLICK, Thomas F., Islamic and Christian Spain in the Early Middle Age. Princeton 1979.

3 It was through Abu 'I-Nâșir's efforts that the famous Persian singer Zyryâb was brought to the Ummayad court in Cordova, where - as is well known - he became the Beau Brummel of the age. See AL-MAQQARî, Nafhal-Tîb (Annalectes sur l'histoire et la littérature des Arabes d'Espagne) II, ed. R. Dozy et al., 1855-1861, págs. 83-90, especially 85.

4 Concerning Hasday's career, see AsHToR, The Jews of Moslem Spain I, págs. 155-277 and the sources cited in the notes, págs. 419-428. 
secular aspects of this Hellenistic high culture in the Muslim oikoumene which facilitated the acculturation of Jews within the society generally. The scientific and philosophical corpus of this high culture was to remain an important element in the paideia of the Sephardi courtier class, not only in al-Andalus, but in the Christian Spain as well, where however, it did not serve as a facilitating factor in the integration of the Jews into the society whose Latin high culture was eminently religious in character. (Although it did allow them to play the role of cultural middle men) ${ }^{5}$.

In addition to establishing the pattern for the Bildungsideal of the formation of the Sephardi courtier, Hasday also provided the model for the courtier's "Lebensstil» and his cultural role within Jewish society. Like many Jews who came near to the seats of Gentile power throughout diaspora history, Hasday acted as the secular leader of the Andalusian Jewish community. According to the Jewish sources, such as the Sêfer ha-Qabbâla of Abraham Ibn Dâ'ûd, he bore the princely Hebrew title of «nâsî», which in Spain did not indicate Davidic descent as it did in the Middle East at that time ${ }^{6}$. However, it was Hasday's title that qualitatively set him apart from other Jewish courtiers in the Islamic world upto this time. What did distinguish him, rather, was his emulation of Muslim officials of high rank who acted as patrons of the arts and sciences.

Hasday went beyond the usual support of religious institutions and traditional scholarship practiced by the Jewish elite almost everywhere in the Diaspora and acted as Maecenas to poets and men of letters, holding his own «môshâvîm», social-cum-literary gatherings, in obvious imitation of the Arab majâlis. At these salons, wine, music, poetry and intellectual conversation and debate all flowed freely. It was in the "môshâv» that Sephardi courtly culture was begotten, a culture that was a Jewish mirror image of the Muslim «Adelskultur». Thus discussions of Hebrew grammar and lexicography replaced Arabic ones. Biblical exegesis replaced koranic «tafsîr» and most notably the composition and recitation of Arabic poetry was replaced by Hebrew versification. Under Hasday's patronage, men like the North-African-born poet Dûnash b. Labrât pioneered in the com-

5 GolteIN, S. D., Studies ir Islamic History and Institutions. Leiden 1966, págs. 54-70; idem, Jews and Arabs: Their contacts through the Ages, rev. ed. New York 1974, pág. 125. It was in fact as a man of science that Hasday comes to be included in the Arab biographical dictionares such as ȘA $\hat{A}^{\mathrm{C} I D}$ AL-ANDALusî, Kitâb Tabaqât al-Umam, ed. L. Cheikho. Beirut 1912, págs. 88f; and IBN ABî ÚSAYBI'A, 'Uyûn al-Anbâ' fî Ṭabaqât al-Ațibbâ', ed. Nizâr Riợâ. Beirut 1965, págs. 494 and 498. (Ibn Abî Ușaybi ${ }^{\circ}$ a borrows heavily from al-Andalusî.)

- IBN DÂ'UD, Sefer ha-Qabbalah, pág. 49 (Heb.); pág. 67 (Eng. tr.). Concerning the «nâsîs» in the Middle East, see GoITEIn, A Mediterranean Society II, pág. 19. 
position of Hebrew poetry employing Arabic metrics and -no less innovatively - secular themes that included an unabashed love of la dolce vita. Dûnash's innovation set the trend that was to become standard for medieval Andalusian Hebrew poetry and was to be the primary medium for the expression of the Sephardi courtier class ethos. In addition to the celebration of the good life, this ethos included the extoling of earthly rank and power and the noble virtues of the patron which paralleled those of the Arab aristrocrat - renowned, generous, just, brave, and merciless with foes. As Dûnâsh lauds Hasday in one of his panegryics:
In East and West his name is great and eminent.
Edom and Arabia speak of his benevolence.
He seeks his people's welfare
And drives away their foes,
Breaking evildoers and cutting off aggressors.
A friend to the many who overlooks their faults,
Speaking gently when he sits in judgment.
$\mathrm{He}$ is like a father to the poor.
His hands are like bountiful clouds to poets,
Raining gold, onyx, and opals not only in winter, but in summer too ${ }^{7}$.

The pattern set by Hasday as an individual in the tenth century, is reproduced many times over in the 11 th century, when the Cordovan Caliphate of the Umayyads breaks up into the petty principalities of the Party Kings («mulûk al-tawâ'if»). Each court in the patchwork of bickering, petty principalities tried to the best of its ability to recreate in miniature the splendor of Cordova. Men of diverse talents were drawn into the service of local rulers. The poitical, ethnic, and social fragmentation of Andalusian society offered an extraordinary opportunity for government service. It is at this time that there arises a relatively significant class of Jewish courtiers with a developed social consciousness, a distinctive lifestyle, and highly evolved self-image (Selbstardstellung). The members of this aristrocracy referred to themselves as "nesî'îm", the princely honorific that in the days of the Cordovan caliphate was reserved for one man alone. They also

SchinmanN, Hayyym [Jefim] , Ha-Shîra hâ-'Turît bi-Sfârâd ûve-Prôvâns I. Jerusalem and Tel Aviv 1961), pág. 39, vv. 59-68. For parallel themes in Arab panegyrics, cf., for example, Ibn Zamrak's encomium for Muhammad V of Granada, in MONROE, James T., Hispano-Arabic Poetry: A Student Anthology. Berkeley, Los Angeles, and London 1974, págs. 346-365; and also Pérès, Henri, La poésie andalouse en arabe classique au xième siècle: ses aspects généraux, ses principaux thème et sa valeur documentaire, $2 \mathrm{dn}$ ed. Paris 1953, págs. 89-90. On the poet as spokesman for the ocurtier and for the ideals of court society, see SCHIRMANN, Jefim [Hayyin], "The function of the Hebrew poet in Medieval Spain", Newish Social Studies, 16:3, 1954, págs. 235-252. 
were designated «nedîîm», another biblical title, which combined the meanings of «noble» and "generous» (like Arabic "karîm») ${ }^{8}$.

These men were not merely the usual physicians, purveyors, clerks and petty bureaucrats found in other Islamic countries at this period. They also included such high-ranking administrators as Abraham Ibn Muhâjir in Seville and Yequtiel Ibn Hasan, the vizier in Saragossa, who was assassinated in 1039 and who was mourned by the young poet Solomon Ibn Gabirol in a famous lament which begins with the lines:

Yequtiel's days have come to an end, A sign the very Heavens were created to pass away ${ }^{9}$.

No office, except that of the ruler himself seemed out of the reach of a talented and ambitious Jew, and the attainment of rank and political power were an express part of the Jewish upper-class ethos. Américo Castro has made much of what he called sthe Judaic dream of grandeur and supremacy», mistaking the ideals of a class with a people as a whole. The late Gerson Cohen, basing himself upon the numerous biblical allusions with their royal and eschatological associations in the poetry of the period, even went so far as to suggest that perhaps the Jewish courtiers had visions of a surrogate messianic age in al-Andalus, which they might bring about by political domination. (I have already expressed my reservations to this suggestion in another essay) ${ }^{10}$.

One courtier did indeed come close to the highest pinnacles of power. In the kingdom of the Berber Zirids in Granada, the office of «kâtib», which was the viziership of state, was held for three decades by Samuel Ibn

\footnotetext{
8 At various times and in various places the titles of «nâsî» and «nâdîv» designated different ranks within the aristocracy, of which that of "nâsî» was higher. See SePTimus, Bernard, «Piety and power in Thirteenth-Century Catalonia», in Studies in Medieval Jewish history and literature, ed. Isadore Twersky. Cambridge, Mass., and London 1979, págs. 223-224, n. 32. The virtue of being "karim" is frequently celebrated in Arabic poetry. See, e.g., the famous poem of al-Samaw'al praising his own tribe (vs. 3), or al-Mutanabbîs celebrated ode lionizing the Hamdanid ruler Sayf al-Dawla (vs, 1), both in ARBERRY, A. J. (ed.), Arabic poetry: A primer for students. Cambridge 1965 , págs. 31 and 85 , respectively.

9 SchIRMANN, ha-Shîra hâ- ${ }^{-}$vrît I, pág. 196 , no. 67 . He wrote other shorter poems on his patron's death. See ibidem., pág. 202, nos. 68 and 69 .

10 CASTro, The Spaniards, págs. 83, 147, and 243. For Cohen's comments on surrogate messianism subliminated into a goal for the attainment of political power, see his edition of Sêfer ha-Qabbalah, págs. 278-289; and my caveats in STILLMAN, Norman A., "Aspects of Jewish life in Islamic Spain", Aspects of Jewish culture in the Middle Age, ed. Paul E. Szarmach. Albany 1979, págs. 64-65. See also Haim Beinart's jaundiced observations regarding the claims put forth by poets that their patrons were scions of the Davidic house in his «DeMưtâh shel ha-Haṣrânût haYehûdît bi-Starad ha-Nôșrît», pág. 63.
} 
Naghrêla — Samuel ha-Nâgîd - and following his death in 1056, for another the years by his son Yehosef.

Samuel ha-Nâgîd was the quintessential representative of the new Andalusian Jewish courtier class and was held up as a paragon by its members and by the men of arts and letters associated with it in the following generations ${ }^{11}$. He was a soldier and politician, an outstanding talmudic scholar, a patron of the arts, a first-rate Arabic scribe and calligrapher, and himself one of the four great masters of medieval Hebrew poetry. Even more than Hasday, he combined the attributes of the Arab «adîb», or cultivated man of letters, and those of the rabbinical scholar. Whereas, $H$ asday had been first and foremost a patron of religious and secular culture, the Nâgîd was also a producer of it. Furthermore, he established a new model for emulation by other members of his class who came after him in both al-Andalus and in Christian Spain, namely that of the rabbi-courtier, an amal-gam idealized by Ibn Dâ'ûd.

Though praised by Ibn Dâ'ûd for his humility, Samuel ha-Nâgîd exhibits all of the hauteur of his class. Never one to suffer from false modesty, the Nâgîd ask himself in one of his poetical meditations: "Are you able of properly praising God?» And he at once responds to his own question with the poetical boast («fakhr»): «l am the David of my generation» ${ }^{12}$.

Samuel ha-Nâgîd's personality was a perfect blend of the tripartite pride in the purity of language, lineage, and religion that characterized the Jewish and the Arab upper classes in al-Andalus —and, I might hasten to add, the ruling noble and clerical classes in Catholic Spain, and the Sephardi elite in the post-Expulsion diaspora. This marked sense of religious, genealogical, and linguistic elitism manifested itself in a variety of ways. The outright persecution of Karaites (or anyone even suspected of Karaite tendencies) in both the Muslim south and the Christian north by courtiers such as Hasday, Samuel ha-Nâgîd, or the Nesîîm Joseph b. Ferrizuel Cidellus and Joseph b. al-Fakhkhär, has its parallel in the Andalusian Muslims' refusal to countenance members of any Islamic rite but the Mâlikî

11 See for example the letter of admonition from Judah B. Tibbon to his son, in KoBLER, Franz (ed.), A treasury of Jewish letters: Letters fromthe famous and the humble 1. Philadelphia 1953), pág. 158, where the Nagid is held up as model; and also IBN DÂ'ÛD, Sêfer ha-Qabbalah, págs. 57-62 (Heb.) and 71-76 (Eng. tr.). For a good biographical sketch of Ibn Naghrêla and an assessment of his oeuvre, see SCHIRMANN, Jefim [Hayyim], "Samuel Hannagid, the man, the soldier, the politician», Jewish Social Studies, no. 8, 1951, págs. 99-126.

${ }_{12}$ Divan Shmuel Hanagid, ed. Dov Jarden. Jerusalem 1966), pág. 33, vs. 38; also in ScHIR-

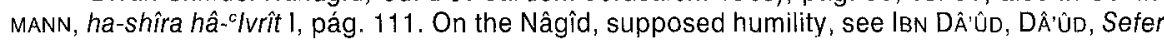
ha-Qabbalah, págs. 56 (Heb.), 76 (Eng. tr.). 
«madhhab», much less the heterodox Shicites or Mu'tazilit es -and of course, later on, for the Spanish Church to tolerate heretics, crypto-Jews and crypto-Muslims, not to mention practicing members of other confessions ${ }^{13}$.

Genealogical elitism was expressed in the claims of some members of the courtier class, such as the Albalia (al-Bâliya) family, to be direct descendants of the Jerusalemite nobility carried off by Titus at the fall of the Second Temple. Moses Ibn, 'Ezra, poet, philosopher, and a member of the courtier class, writes in his work on the Hispano-Hebraic ars poetica, the Kitâb al-Muhâdara wa I-Mự̂hâkara, that Iberian Jewry as whole was nothing less than the descendants of the people of Jerusalem who surpassed all other Israelites «in the purity of language and the tradition of legal science (i.e., halakhic scholarship)". Here the other two forms of purity - linguistic and religious - are explained by the impeccability of the pedigree. The noble Jerusalemite lineage of Sephardi Jewry becomes a widely-held article of faith among Iberian Jewry generally and the courtier elite in particular probably based originally upon the prophecy in Obadiah 20 mentioning the return of "the Jerusalemite exile community of Sepharad». (This belief was not without some historical foundation since the second-century midrashic chronicle Sêder 'Ôlâm does record that many Judean families, including those of the Davidic line were carried off into exile in Spain). Three centuries after Ibn 'Ezra, R. Moses Arragel takes up a similar theme in the commentary to his Castilian translation of the Hebrew Bible, and Don Issac Abravanel, a generation after Arragel, was claiming to be of Davidic descent and that his ancestors had come to Iberia even before the Roman period. (Claims of such a venerable origin and of antiquity in Spain had unded the Christian monarchies, as has been noted by scholars, a distinct apologetic character in addition to pride of pedigree, since it showed the Iberian Jewry, or at least its aristrocracy, had been in Iberia since before the crucifixion). The later insistence of the elite «Megôrâshîm» in the post-Expulsion diaspora upon their being Sefaradîm T hôrim («pure Sephardim») reflects this same pride of lineage ${ }^{14}$.

${ }^{13}$ On the persecution of the Karaites, see BARzILLAY, Judah b., Sêfer hâ-' lttîm, ed. J. Schorr. Cracow 1903, pág. 267; IBN DÂ'ûd, Sefer ha-Qabbalah, págs. 69-72 (Heb.) and 94-101 (Eng. tr.); BAER, The Jews in Christian Spain l, págs, 65 and 390-391, $\mathrm{n}$. 45. Ont he treatment of nonMâlikîs in al.Andalus, see AL-MUQAD DASî, Ahsan al-Taqâsîm fî Márifat al-Aqâlim, ed. M. J. de Goeje. Leiden 1906), pág. 236; and also Asín Palacios, Miguel, «lbn Masarra y su escuela», in Obras escogidas I. Madrid 1946, pág. 25.

14 IBN DÁ'ÛD, Sefer ha-Qabbalah, págs. 58 (Heb.) and 79 (Engl. tr.); Sêder 'Olâm in NEUBAUER, A., Mediaeval Jewish chronicles and chronological notes I. Oxford 1887, pág. 175; 'EzRA, Moses b., Sêfer Shîrat Yisrâ'êl (Kitâb al-Muhâdara wa 'I-Mudhâkara), Heb. tr. by B. Halper. Jerusalem 1727), pág. 62; BAER, The Jews in Christian Spain II, págs. 252-253; NeTANYAHu, B., Don 
Américo Castro has argued that the Spanish obsession with notions of "Castizo" and «limpieza de sangre» is a cultural borrowing from Sephardi Jewry. Although this may be the case given the pervasiveness of intercultural influences in medieval Iberia, the evidence he cites is nor sufficiently convincing ${ }^{15}$.

The Sephardi courtier elite's emphasis upon lineage within the broader context of religious and linguistic purity must be understood within the context of its through acculturation of Arab social norms by the time it emerges as a conscious group in the tenth and eleventh centuries. The emphasis upon genealogy, consanguinity, and agnatic relations was an integral part of tribal ideals of both the Arab and Berber settlers who came to al-Andalus in the eighth century and remained so even after the breakdown of the tribal system. The superiority of Arab stock, its Arabian homeland, and the Arabic language, all of which can be summed up under the notion of "Carabiyya", became articles of the Arab elite's social vision and were challenged by the Muwallad Shucûbiyya which arose in the eleventh century ${ }^{16}$.

Linguistic purity was a concomitant of genealogical nobility. Among the Andalusian Jewish upper class this notion was manifested in a penchant for Hebrew grammatical studies and the cultivation of poetry which was considered the ultimate national art form in Arabi society in a classicizing biblical Hebrew that was the Jewish parallel of «al-carabiyya al-fușhâ». There was clearly a strong element of reactive acculturation here. Good style

Isaac Abravanel statesman and philosopher. Philadelphia 1953, págs. 3 and 266, n. 6; HiLleL BEN-SASSON, Hayyim, "Dôr Gôlê Sefârad 'al "Așmô", Zion, no. 26, 1961, págs. 23-25; and BElNART, «Demûtầh shel ha-Hașrânût ha-Yehûdît bi-Sfarad ha-Noșrît», pág. 63. Concern with lineage (Heb. yihûs) was, of course, not something exclusive among Sephardi Jewry. Genealogies had become important in some Jewish circles from the period following the Babylonian exyle. However, the general emphasis upon nobility of origin seems to have been particularly characteristic of Iberian Jewry.

15 CaSTRO, The Spaniards, págs. 71-80. See specially págs. 75f, where Castro fails to understand the religious context of a case involving țaharat ha-mishpâha (family purity). The case is discussed in full in NeUman, Abraham A., The Jews in Spain: Their social, political and cultural life during the Middle Age II. Philadelphia 1944, págs. 4-8.

16 For important anthropological observations on the importance of kinship and lineage in Muslim social structure in al-Andalus, see GLICK, Islamic and Christian Spain, págs. 137-141. On Arabism asstimulus to Jewish social thinking, see AlLony, Nehemya, "The reaction of Moses Ibn Ezra to "Arabiyya (Arabism)", Etudes hébraiques: Actes du XXIXème Congrès international des Orientalistes. Section organisée par Georges Vajda. Paris 1975, págs. 1-16. On Shu'ûbî attacks upon Arab superiority and the response, see MONROE, James T., The Shu ûbiyya in alAndalus: The Risâla of Ibn García and Five Refutations. Berkeley, Los Angeles, and London 1970; GoLdZIHER, Ignaz, "Die Shu'ûbiyya unter den Muhammedanern in Spanien», ZDMG, 53:4, 1899, págs. 601-620. 
in Arabic and later Castilian were cultivated for entrée and advancement within Gentile society. And some Jews at times did turn their hand to writing Arabic verses, even as later in Christian Spain some produced courtly poems in Castilian. Hebrew belles-lettres in a purist literary idiom were clearly cultivated as a national response of a subordinate toa dominant groupág. Judah al-Harîzî states outright that he wrote his Tahkemônî in obvious emulation of the Arabic tour de force the Maqâmât of alHarîrî, in orden «to show th power of the Holy Language to the Holy People» "'. Linguistic purism can also be seen in later Sephardi courtiers' attempts in the post-Expulsion period in to maintain the use of Castilian Spanish rather than Ladino for official purposes. The eighteenth-century Italian Jewish poet and adventurer Samuel Romanelli relates that in his first meeting in Tangier with Eliyahu Levi, one of the most powerful courtiers in the entourage of the Sherifan Sultan Sîdî Muṇammad b. ${ }^{\mathrm{C}} \mathrm{Abd}$ Allâh, the Moroccan Jewish courtier addressed him «in pure Spanish» (that is, neither in Haketía, nor in Judeo-Arabic). This was a mark of his culture and his aristocracy ${ }^{18}$.

In addition to the tripartite pride of language, lineage, and religion which also was a hallmark of the Arab ruling class, members of the Jewish courtier elite frequently conducted themseles with the lofty demeanor and comportment that traditionally had marked those who wielded power in the Middle East even before the rise of Islam. The courtiers' hauteur was in no small measure based upon the generally-held conviction that social rank and temporal authority were divinely ordained. (As a famous talmudic maxim states: "even the most insignificant of the insignificant, once he is appointed to a position of public authority, is to be regarded as the noblest of the noble» ${ }^{19}$.

Muslim traditionalists, naturally, found such pretentiousness on the part of dhimmis to be an affront to Islam and an express violation of the Pact of 'Umar. Christian zealots were no less offended by what they perceived as the arrogance of Jewish officials. But even Jewish moralists from

17 Judha AL-Harî̀î, Tahkemônî, ed. Y Toporovsky. Tel Aviv 1952, pág. 12. For examples of Jews writing Arabic verses, see STERN, S. M., "Arabic poems by Spanish-Hebrew poets", in Romanica et Occidentalia: Etudes dédiées à la mémoire de Hiram Peri (Pflaum), ed. Moshé Lazar. Jerusalem 1963, págs. 254-263.

18 RomanelLI, Samuel, Travail in an Arab Land, tr. Yedida K. Stillman and Norman A. Stillman. Tuscaloosa and London 1989, pág. 78. Romanelli (ibidem, pág. 39) also mentions meeting a woman of the Sephardi upper class in Tangier who could recite passages from Lope de Vega.

19 BT Tractate Rosh ha-Sahan 25b. The New Testament also views temporal power as a reflection of Divine authority. See Paul's famous admonition to Christians regarding their obligation to obey men in authority in Romans 13:1-7. 
Bahya Ibn Paquida on rail against the haughtiness and other contemptible traits of the Sephardi aristrocracy. Bahya specifically singles out their «love of authority and honor, arrogance and pride, haughtiness and vulgarity». Three and a half centuries after Bahya wrote these lines, Solomon Alami depicts the Jewish courtiers of his day as «insolent in their wealth and gratness». He goes on say:

And they built palaces and took for themselves large and good mules for their chariots... And their wives and duaghters dressed like princesses and great ladies. And they despised religion and humility and all work and handicraft...

More than three and a half century again, Romanelli expresses his chagrin at the ostentation of Sephardi courtiers in Morocco, like Mordechai al-Hazzân Bekkâ of Meknes, who though learned, honest, and a sincere advocate of his people, went beyond all bounds of public display by «riding through the marketplace and streets already a violation of the dhimmî code in Muslim eyes] while smoking» ${ }^{20}$.

Even more than their hauteur, it was the ethical and moral conduct of many membrs of the courtier class both in their private and political lives and in their dealings with their fellow Jews that came under criticism throughout the ages. From the time the courtier class first emerges in the period of the Umayyad caliphate and the Party Kings, it had clearly adopted many of the mores of upper class Muslim society. Acculturation went much deeper than merely living in luxury and holding soirées. The hedonism of court poetry was not merely a theoretical exercise in imitating Arabic literary «topoi», as some scholars have argued unconvincingly. Rather, it must be considered a genuine reflection of aristocratic life. Flirtation, love affairs, concubinage, and even pederasty were part of the courtiers' lifestyle despite the contravention of Jewish religious values. As Raymond Scheindlin has so aptly put it, "the same reasoning that led us to affirm the participation of Jews in wine parties would lead us to affirm cautiously their participation in the kind of love life fashionable in their milieu". There exists at least some sources both Jewish and non-Jewish outside of the poetry itself to corroborate this view ${ }^{21}$.

20 BAhya B. PaQÛda, Kitâb al-Hidâya ilâ Farâ'iợ-al-Qulûb, ed. J. Kafih.- Jerusalem 1973, pág. 159. Seealso Bezalel Safran, Bahya ibn Paquda's Attitude toward the Courtier Class", in Studies in Medieval Jewish History and Litterature, ed. Isadore Twersky. Cambridge, Mass., and London 1979), págs. 154-196. AlAMI, Solomon, Iggeret Mûsar cited in BAER, The Jews in Christian Spain II, pág. 242. RomanelLI, Travail in an Arab land, pág. 115.

${ }_{21}$ Scheindlin, Raymond P., Wine, women and death: Medieval Hebrew poems on the good life. Philadelphia 1986, pág. 86. The first scholar to definitively point to the homosexual content 
During the Christian period, easy sexual morals and romantic adventures seem not to have been uncommon among the Jewish courtiers as the poetry of Todrôs ha-Levi Abulafia testifies on the one hand, and the censure of moralists and the cases discussed in some of the responsa literature bear witness on the other ${ }^{22}$. The Kabbalists of the thirteenth and fourteenth centuries decry the sexual mores of many members of the courtier class and attribute them on their philosophical rationalism:

Philosophy itself is] a rationalization of their indulgence in sensual pleasure... Hence they are ever in pursuit of iniquity; they are quick to shed blood and are eager to fornicate, and ready to violate all the precepts of the Torah $^{23}$.

The combination of violence and sensuality coupled with secular high culture, lambasted in the passage above, was a hallmark of court life with all of its luxurious pomp, its cultural glitter, and its base intrigue under both Muslim and Christian rulers. Although the Jewish courtiers maintained a considerable measure of class salidarity, cementing their ties by intermarriage amongst families of their own set, they could indulge in the same deadly personal rivalries with coreligionists as did non-Jewish courtiers. As Haim Beinart has aptly pointed out while making no apologies for them, many Jewish courtiers were swept up into the Hobbesian brutishness of their milieu and were pushed on by their instinct for selfpreservation. At times, their interests -indeed their survival - and the interests of the Jewish community were not necessarily the same. This was particularly true in the case of tax farmers and those responsible for collecting levies from the Jewish community ${ }^{24}$.

of medieval Andalusian love Lyrics was SCHiRmanN, Jefim [Hayyim], "The Ephebe in Medieval Hevrew poetry", Sefarad, 15:1, 1955, págs. 55-68. This article elicited a very unconvincing rebuttal by AlLoNy, Nehemia, "The "Zevi" (Nasib) in the Hebrew poetry of Spain", Sefarad, 23:2, 1963, págs. 311-321. For a good survey of some of the corroborating literature on pederasty, see Rотн, Norman, «Deal gently with the young man: Love of boys in Medieval Hebrew poetry of Spain», Speculum, 567: 1, 1982, págs. 20-51.

22 Concerning Todros ha-Levi and his poetry, see Doron, Aviva, Meshôrêr be-Hasêr haMelekh: Todrôs ha-Lêvi Abûl'afiya: Shîra 'Ivrît bi-Sfarad ha-Nôsrît. Tel Aviv 1989); also BAER, The Jews in Christian Spain I, págs. 237-239; and BEINART, "Demûtâh shel ha-Hașranût ha-Yehûdît bi-Sfarad ha-Nôșrît», pág. 64. For numerous cases of sexual immorality culled just from the responsa of R. Solomon b. Adret, R. Asher, and R. Judah b. Asher, see the references cited in Neuman, The Jews in Spain II, pág. 278, n. 22, Paras. C and D. For an excellent survey of sexual mores during this period, see Assis, Yom Tov, "Sexual behavior in medieval Hispano-Jewish society", in Jewish history: Essays in honour of Chimen Abramsky, eds. A. Rapoport-Albert and S. J. Zipperstein. London 1988, págs. 25-59.

${ }^{23}$ Quoted in BAER, The Jews in Christian Spain II, pág. 241.

24 BEINART, Haim, "Demûtâh shel ha-Hașranût ha-Yehûdît bi-Sfârad ha-nôșrît», págs. 59 and $62-63$ 
The necessity for hardness, even cruelty, in the political and professional lives of many courtiers sometimes was carried over into their private lives and into their dealings with their fellow Jews outside of aristocratic circles. Manahem b. Sarûq complains bitterly about the brutal treatment he received from Hasday Ibn Shaprûtț's thugs after being unjustly banished from the Nâsî's entourage. Joseph b. Todros in thirteenth-century Castile inveighs against the "fat", "arrogant", and uncaring Jewish aristocrats "who thrust the poor off the road, who forsake the paths of equity». In his lggeret Mûsâr written in 1415, Solomon Alami exhorts the Sephardi grandees whom he calls "shedders of innocent blood» and «oppressers of their inferiors» to reform their conduct so that they might use their privileged positions to serve their coreligionists as they ought. Several decades earlier, Don Joseph Ibn Shoshan had spelled out just how the courtier was to use his high office:

«lt is an ordinance incumbent upon every son of the Covenant that if he should attain a position in government... he should see himself as if he is the messenger of the Omnipresent (blessed be $\mathrm{He}$ ) Who directs the currents of king's heart and caused him to enter the king's favor so that his words might be heard and acted upon when he stands before him in the breach for the sake of God's holy people» ${ }^{25}$.

There were, of course, numerous Jewish courtiers throughout all of the centuries both in Spain and the lands of the post-Expulsion dispersion who lived by the ideals enunciated by Ibn Shoshan. In Sacadian Morocco, for example, members of the Sephardi aristocracy, such as Jacob Rosales, Abraham Ben Zamiro and Jacob and Arbraham Rote, found places in the Sherifan sultans' service and took on active roles as protectors and leaders of the Jewish community. They had their counterparts at the Ottoman Sublime Porte in the persons of men like Joseph and Moses Hamon, Don Joseph Nasi, and Solomon Ibn Ya ${ }^{a} i s^{26}$.

There were, however, both before and after the Expulsion many courtiers who were not such exemplary figures. Haim Hillel Ben-Sasson has noted that the first generation of exiles from Spain tended to idealize the courtiers of the past and looked with pride upon the phenomenon as a

25 See Menahem's poetic letter of complaint to his former master in SCHIRMANN, ha-Shira hâ- ${ }^{\circ}$ vrît bi-Sfârad ûve-Prôvans I, págs. 8-30. For the epistles of Joseph b. Todros and Solomon Alami, see BAER, The Jews in Christian Spain I, pág. 108 and II, pág. 242, respectively. For the quotation from Don Joseph b. Shoshan's commentary on the talmudic tractate Avot, see BENSASSON, "Dôr Gôlê Sefârad "al "așmô", págs. 29-30.

${ }_{26}$ Concerning all of these individuals, see StILLman, Norman A., The Jews of Arab lands: A history and source book. Philadelphia 1979, index, swv. 
whole. Although it should be noted that a considerable part of the sources examined by Ben-Sasson emanated from an upper class milieu. It was not too long before voices of disillusionment with the courtier institution would be raised, as we find with $R$. Solomon $b$. Isaac ha-Levi in Salonika during the second half of the sixteenth century ${ }^{27}$.

No indictment is more damning than of Romanelli for the Jewish courtiers in eighteenth-century Sherifan Morocco. According to him, these men, most of whom were descendants of the Sephardi elite:

know nothing of benevolence. They thrive on the destruction of others. They would disown their father and mothers... would not recognize their brothers, nor would they even know their own children. Such a man would befriend another in word and win his heart, present him with a gift, and then return to plot his murder... I have found only one in a thousand who graced others with his goodness ${ }^{28}$.

Despite the perennial critiques of moralists and of antiaristocratic populists - not to mention the vicissitudes of service in Muslim regimes that were always fraught with danger for anyone, dhimmi or Muslim - the Sephardi courtier class continued to play a leading role in Jewish communities from Morocco to Ottoman Turkey and the Levant all the way down to modern times. Though patriarchal and socially conservative in many respects, many members of this group became important agents of modernization within their communities in the nineteenth and twentieth centuries $^{29}$.

27 See Hacker, Joseph, «Yisrâ'êl ba-Gôyyîm be-Te'ûrô shel R. Shelomo le-Bêt ha-Lêvî miSalônîkî̀, Zion, no. 34, 1969, pág. 73.

28 ROMANELL, Travain in an Arab land, págs. 79-80.

29 See StILLMan, Norman A., The Jews of Arab Lands in Modern Times. Philadelphia 1991, págs. $6,11,21$, and $43-44$. 